\title{
PENGARUH PENDIDIKAN KESEHATAN TENTANG SADARI SEBAGAI DETEKSI DINI KANKER PAYUDARA TERHADAP PENGETAHUAN DAN SIKAP SISWI SMK SWASTA YAPIM BALIGE TAHUN 2020
}

\author{
Dosmaida Nababan \\ Program Studi D-III Keperawatan, STIKes Arjuna \\ Email : dosmaidan@gmail.com
}

\begin{abstract}
This study aims to determine the effect of health education on BSE as an early detection of breast cancer on the knowledge and attitudes of Yapim Vocational School students, Balige District, Tobasamosir Regency in 2020. This research is a quasi-experimental research type, using the pretest-posttest design method, namely by how to give a pre test (initial observation) before the intervention is carried out, after being given the intervention then a post test (final observation) is carried out. The research was conducted at Yapim Vocational High School, Balige District, Toba Samosir Regency, from January to March 2020. The research subjects were a total of 91 Yapim Balige Vocational School students. The statistical test used is the Wilcoxon test. The results of the pair t-test analysis of pre-test and post-test of knowledge. So, it is concluded that there is an effect of health education on BSE on student knowledge. The result of pair t-test analysis result pre test and post test attitude obtained $p$ value $=0.000$, meaning $p$ value $>0.05$. So, there is an effect of health education about BSE on student attitudes. So, it is hoped that the Tobasa Health Office will make a work program of health education or a routine schedule of health counseling and to continuously socialize health information about Sadari, especially to schools in Tobasa so that students know and do Realize so they can detect breast cancer early.
\end{abstract}

Keywords: Health education, Knowledge, Attitudes, SADARI

\begin{abstract}
Abstrak
Penelitian ini bertujuan untuk mengetahui pengaruh pendidikan kesehatan tentang SADARI sebagai deteksi dini kanker payudara terhadap pengetahuan dan sikap siswi SMK Swasta Yapim Kecamatan Balige Kabupaten Tobasamosir Tahun 2020. Penelitian ini merupakan jenis penelitian eksperimen semu atau quasi experiment, menggunakan metode pretest-posttest design, yaitu dengan cara memberikan pre test (pengamatan awal) terlebih dahulu sebelum dilakukan intervensi, setelah diberikan intervensi kemudian dilakukan post test (pengamatan akhir). Penelitian dilaksanakan di SMK Swasta Yapim Kecamatan Balige Kabupaten Toba samosir pada bulan Januari s/d Maret 2020. Subyek penelitian adalah total seluruh Siswi SMK Swasta Yapim Balige yang berjumlah 91 siswi. Uji statistik yang digunakan adalah uji wilcoxon. Hasil analisa uji pair ttest pre test dan post test pengetahuan. Maka, disimpulkan ada pengaruh pendidikan kesehatan tentang SADARI terhadap pengetahuan siswi. Hasil analisa uji pair t-test pre test dan post test sikap diperoleh nilai $p=0.000$, berarti nilai $p>0.05$. Maka, ada pengaruh pendidikan kesehatan tentang SADARI terhadap sikap siswi. Sehingga, diharapkan kepada Dinas Kesehatan Tobasa untuk membuat program kerja penyuluhan kesehatan atau jadwal rutin penyuluhan kesehatan serta mensosialisasikan informasi kesehatan secara terus menerus tentang Sadari terutama ke sekolah yang ada di Tobasa sehingga siswi mengetahui dan melakukan Sadari sehingga dapat mendeteksi dini kanker payudara.
\end{abstract}

Kata kunci: Pendidikan kesehatan, Pengetahuan, Sikap, SADARI 


\section{PENDAHULUAN}

Kanker payudara merupakan penyakit menakutkan bagi kaum wanita karena sampai pada saat ini walaupun teknologi kedokteran dan medicine telah berkembang pesat, belum ditemukan obat yang manjur untuk menyembuhkan kanker payudara. Kanker payudara merupakan penyakit neoplasma yang ganas berasal dari parenchym, penyakit yang dapat menimbulkan kesengsaraan. Pada umumnya kanker payudara merupakan tumor ganas yang menyerang jaringan payudara, yang terdiri dari kelenjar susu (kelenjar pembuat air susu), saluran kelenjar (saluran air susu) dan jaringan penunjang payudara.

Menurut data WHO tahun 2013, insiden kanker meningkat dari 12,7 juta kasus tahun 2008 menjadi 14,1 juta kasus tahun 2012. Sedangkan jumlah kematian meningkat dari 7,6 juta orang tahun 2008 menjadi 8,2 juta tahun 2012. Kanker menjadi penyebab kematian nomor 2 di dunia sebesar $13 \%$ setelah penyakit kardiovaskular. Bahkan, diperkirakan tahun 2030 insidens kanker mencapai 26 juta orang dan 17 juta diantaranya meninggal akibat kanker, terlebih untuk negara miskin dan berkembang kejadiannya akan lebih cepat.

Menurut Sistim Informasi Rumah Sakit (SIRS) jenis penyakit tertinggi adalah kanker payudara yaitu sebanyak $18,4 \%$, yang lebih sering menyerang usia 30 tahun dan sekarang wanita usia remaja. Hal ini didukung dari laporan WHO 2005 jumlah remaja penderita kanker payudara mencapai 1.150.000 orang, 700 diantaranya tinggal di negara berkembang. Sedangkan di RSUD Prof.Dr.H.Aloe Sabo Kota Gorontalo pada tahun 2012 ditemukan 7 kasus kanker payudara pada remaja usia 16 dan 18 tahun. Sedangkan data dari RS dr. Pirngadi, jumlah penderita kanker payudara tahun 2011 ditemukan 2 kasus pada remaja usia 17 dan 18 tahun dan banyak ditemukan penderita kanker payudara usia muda, bahkan tidak sedikit remaja putri usia 14 tahun menderita tumor payudara, yang menjadi kanker jika tidak terdeteksi lebih awal.
Di Indonesia, prevalensi penyakit kanker juga cukup tinggi. Berdasarkan data Riset Kesehatan Dasar (Riskesdas) tahun 2013, prevalensi tumor/kanker di Indonesia adalah 1,4/1000 penduduk atau sekitar 330.000 orang. Data dari Yayasan Kanker Indonesia (YKI) pada lima tahun terakhir menyebutkan kejadian kanker payudara menempati urutan pertama, yaitu 32\%, dari total jumlah kasus kanker. Total penderita kanker payudara sebanyak $40 \%$ berobat pada stadium awal, 30\% dari total jumlah penderita kanker terdeteksi stadium lanjut lokal dan 30\% dengan metastasi.

Menurut WHO, satu-satunya cara yang efektif sampai saat ini dengan melakukan deteksi sedini mungkin yaitu dengan melakukan Pemeriksaan Payudara Sendiri (SADARI). Tindakan ini sangat penting karena hampir $85 \%$ benjolan payudara ditemukan oleh penderita sendiri. Hal ini dikarenakan penyebab terjadinya kanker payudara sampai saat ini belum diketahui. Untuk mendeteksi secara dini adanya kelainan pada payudara, diantaranya dengan thermography, mammography, ductography, biopsi dan USG payudara. SADARI yaitu pemeriksaan yang mudah dilakukan oleh setiap wanita untuk mengetahui adanya benjolan atau kelainan payudara lainnya, yang bertujuan untuk menemukan kanker dalam stadium dini sehingga pengobatannya menjadi lebih baik. Ternyata $75-82 \%$ keganasan payudara ditemukan pada saat dilakukan pemeriksaan payudara sendiri.

Mengingat masih banyak siswi yang belum mengetahui tentang kesehatan reproduksi, khususnya pengetahuan tentang kanker payudara dan praktik SADARI, sangatlah penting untuk dilakukan pendidikan kesehatan dengan harapan dapat mengubah pengetahuan dan sikap tentang kanker payudara pada siswi SMK Swasta Yapim Balige. Dari hasil survey pendahuluan yang dilakukan peneliti pada siswi SMK Swasta Yapim Balige dengan kuesioner 40 siswi kelas XII, 30 orang pernah mendengar penyuluhan tentang SADARI, tetapi tidak pernah melakukannya. 
Sedangkan 10 siswa menjawab tidak pernah mendapatkan informasi tentang SADARI. Sehingga, perlu diadakan pendidikan kesehatan tentang SADARI untuk meningkatkan pengetahuan siswi sehingga mengetahui dan mau serta melakukannya. Menurut informasi dari dinas kesehatan Tobasamosir, bahwa jadwal penyuluhan tentang sadari tidak terjadwal ke SMK hanya dilakukan kepada masyarakat umum.

$$
\text { Upaya peningkatan derajat }
$$

kesehatan masyarakat didasari pemikiran bahwa sekolah merupakan lembaga yang sengaja didirikan untuk membina dan meningkatkan kualitas SDM, baik fisik, mental maupun spiritual. Berdasarkan uraian di atas dan informasi kasus kanker dengan insiden tertinggi pada perempuan dengan kanker payudara, maka perlu adanya upaya pendeteksian dini kanker/tumor payudara pada tingkat sekolah menengah atas, dengan memberikan pendidikan kesehatan.

\section{METODE PENELITIAN}

Penelitian ini merupakan jenis penelitian eksperimen semu atau quasi experimen yang bertujuan untuk menguji perubahan pengetahuan, sikap dan tindakan pada siswi berdasarkan perlakuan berupa pendidikan kesehatan tentang SADARI. Penelitian ini menggunakan metode pretestposttest design, yaitu dengan cara memberikan pretest (pengamatan awal) terlebih dahulu sebelum dilakukan intervensi, setelah diberikan intervensi kemudian dilakukan posttest (pengamatan akhir). Penelitian dilaksanakan di SMK Swasta Yapim Balige Kecamatan Laguboti Kabupaten Tobasa pada bulan Januari s/d Maret 2020. Adapun populasi penelitian yaitu seluruh siswi SMK Swasta Yapim Balige Kecamatan Balige Kabupaten Tobasa yang berjumlah 171 siswi. Sedangkan sampel penelitian bagian dari populasi yang akan digunakan untuk penelitian. Sampel dalam penelitian ini adalah total sampling yaitu seluruh siswi SMK Swasta Yapim Balige kelas XII yang berjumlah 91 siswi. Uji statistik yang digunakan adalah uji Wilcoxon.
HASIL PENELITIAN

Hasil Penelitian Analisis Univariat

Tabel 1. Distribusi Frekuensi Umur Siswi di SMK Swasta Yapim Balige

\begin{tabular}{lllc}
\hline No. & Umur & F & \% \\
\hline 1 & 16 Tahun & 12 & 13.2 \\
2 & 17 Tahun & 54 & 59.3 \\
3 & 18 Tahun & 25 & 27.5 \\
\hline & Total & 91 & 100 \\
\hline
\end{tabular}

Dari tabel di atas, disimpulkan bahwa mayoritas umur siswi yang berumur 17 tahun sebanyak 54 siswi (59.3\%) dan minoritas siswi dengan umur 16 tahun sebanyak 12 siswi (13.2\%).

Tabel 2. Distribusi Frekuensi Pengetahuan Pre Test Siswi tentang Sadari SMK Swasta Yapim Balige

\begin{tabular}{llcc}
\hline No & Umur & F & \% \\
\hline 1 & Kurang & 8 & 8.8 \\
\hline 2 & Cukup & 51 & 56.0 \\
\hline 3 & Baik & 32 & 35.2 \\
\hline & Total & 91 & 100 \\
\hline
\end{tabular}

Dari tabel di atas, disimpulkan bahwa pengetahuan pre test siswi SMK Swasta Yapim Balige mayoritas memiliki pengetahuan yang kurang dengan jumlah 51 siswi (56.0\%) dan minoritas siswi memiliki pengetahuan yang kurang dengan jumlah 8 siswa $(8.8 \%)$.

Tabel 3. Distribusi Frekuensi Pengetahuan Post Test Siswi tentang Sadari di SMK Swasta Yapim Balige Laguboti

\begin{tabular}{lllc}
\hline No. & Pengetahuan & F & \% \\
\hline 1 & Kurang & 1 & 1.1 \\
2 & Cukup & 22 & 24.2 \\
3 & Baik & 68 & 74.7 \\
\hline & Total & 91 & 100 \\
\hline
\end{tabular}

Dari tabel di atas, disimpulkan bahwa pengetahuan post test siswi SMK Swasta Yapim Balige mayoritas memiliki pengetahuan yang baik dengan jumlah 68 siswi $(74.7 \%)$ dan minoritas siswi memiliki pengetahuan yang kurang dengan jumlah 1 siswa $(1.1 \%)$. 
Tabel 4. Distribusi Frekuensi Sikap Pre Test Siswi tentang Sadari di SMK SMK Swasta Yapim Balige

\begin{tabular}{llcc}
\hline No. & Sikap & F & \% \\
\hline 1 & Negatif & 0 & 0 \\
2 & Positif & 91 & 100 \\
\hline & Total & 91 & 100 \\
\hline
\end{tabular}

Dari tabel di atas, disimpulkan bahwa sikap pre test siswi SMK Swasta Yapim Balige mayoritas memiliki sikap baik dengan jumlah 91 siswi (100\%) dan tidak ada sikap negatif pada siswi di SMK tersebut.

Tabel 5. Distribusi Frekuensi Sikap Post Test Siswi tentang Sadari di SMK SMK Swasta Yapim Balige

\begin{tabular}{llcc}
\hline No & Sikap & F & \% \\
\hline 1 & Negatif & 0 & 0 \\
2 & Positif & 91 & 100 \\
\hline & Total & 91 & 100 \\
\hline
\end{tabular}

Dari tabel di atas, disimpulkan bahwa sikap post test siswi SMK Swasta Yapim Balige mayoritas memiliki sikap baik dengan jumlah 91 orang $(100 \%)$ dan tidak ada sikap negatif pada siswi di SMK tersebut.

Analisis Bivariat

Tabel 6. Rata-rata Pengetahuan Siswi tentang Sadari di SMK Swasta Yapim Balige

\begin{tabular}{ccccc}
\hline Pengetahuan & Mean & N & SD & $\begin{array}{c}\text { Std Error } \\
\text { Mean }\end{array}$ \\
\hline Pre test & 12.58 & 91 & 2.071 & .217 \\
Post test & 14.51 & 91 & 1.587 & .166 \\
\hline \multicolumn{2}{c}{ Dari tabel di } & atas, & terlihat & statistik
\end{tabular}

deskriptif berupa rata-rata pengetahuan pre test dan post test dan standar deviasi pengetahuan pre test dan post test. Rata-rata pengukuran pertama untuk pengetahuan pre test adalah 12.58 dengan standar deviasi 2.071. Pada pengukuran kedua didapat ratarata untuk pengetahuan post test adalah 14.51 dengan standar deviasi 1.587 .
Tabel 7. Pengaruh Perbedaan Pengetahuan Pre Test dan Post Test Siswi tentang Sadari di SMK Swasta Yapim Balige

\begin{tabular}{|c|c|c|c|}
\hline \multicolumn{4}{|c|}{ Paired Sample T Test } \\
\hline \multirow{3}{*}{$\begin{array}{l}\text { Penget } \\
\text { ahuan } \\
\text { Pre test }\end{array}$} & \multicolumn{2}{|c|}{$95 \% \mathrm{CI}$} & \multirow{2}{*}{$\begin{array}{l}\text { Sig (2- } \\
\text { tailed) }\end{array}$} \\
\hline & Lower & Upper & \\
\hline & -2.300 & -1.546 & 0.000 \\
\hline
\end{tabular}

Dari tabel di atas, terlihat nilai perbedaan mean antara pengukuran pengetahuan pre test dan post test sebesar 1.923 dengan standar deviasi 1.809. Hasil uji statistik didapatkan nilai sig 0.000. Maka, disimpulkan ada perbedaan yang signifikan antara pengetahuan pre test dan post test. Siswi SMK Swasta Yapim Balige memiliki perubahan pengetahuan sebelum dilakukan edukasi dan praktek tentang sadari dengan setelah dilakukan edukasi dan praktek.

Tabel 8. Rata-rata Sikap Siswi tentang Sadari di SMK SMK Swasta Yapim Balige

\begin{tabular}{ccccc}
\hline Sikap & Mean & N & SD & Std Error Mean \\
\hline Pre test & 41.58 & 91 & 3.922 & .411 \\
Post test & 43.35 & 91 & 4.135 & .433 \\
\hline
\end{tabular}

Dari tabel di atas, terlihat statistik deskriptif berupa rata-rata sikap pre test dan post test dan standar deviasi sikap pre test dan post test. Rata-rata pengukuran pertama untuk sikap pre test adalah 41.58 dengan standar deviasi 3.922. Pada pengukuran kedua diperoleh rata-rata untuk sikap post test adalah 43.35 dengan standar deviasi 4.135 .

Tabel 9. Pengaruh Perbedaan Sikap Pre test dan Post test Siswi tentang Sadari di SMK Swasta Yapim Balige

\begin{tabular}{|c|c|c|c|c|}
\hline \multirow{3}{*}{$\overline{\text { Sikap }}$} & \multicolumn{3}{|c|}{ Paired Sample T Test } & \multirow{3}{*}{$\begin{array}{l}\text { Sig (2- } \\
\text { tailed) }\end{array}$} \\
\hline & \multirow{2}{*}{ Mean } & \multicolumn{2}{|c|}{$95 \% \mathrm{CI}$} & \\
\hline & & Lower & Upper & \\
\hline $\begin{array}{l}\text { Pre test } \\
\text { Post test }\end{array}$ & -1.769 & -2.380 & -1.158 & 0.000 \\
\hline
\end{tabular}

Dari tabel di atas, terlihat perbedaan mean antara pengukuran sikap pre test dan post test sebesar 1.769 standar deviasi 2.933. 
Hasil uji statistik diperoleh nilai sig 0.000 . Maka, disimpulkan ada perbedaan yang signifikan antara sikap pre test dan post test. Siswi SMK Swasta Yapim Balige memiliki perubahan sikap sebelum dilakukan edukasi dan praktek tentang sadari setelah dilakukan edukasi dan praktek.

\section{PEMBAHASAN}

Berdasarkan hasil penelitian diketahui bahwa semua item pertanyaan pengetahuan mengalami peningkatan, yaitu sebelum penyuluhan sebagian besar pengetahuan responden pada kategori kurang. Sebelum diberikan penyuluhan diketahui sebagian besar responden menjawab salah pada semua item pertanyaan. Pertanyaan yang sebagian besar dijawab dengan tepat adalah pertanyaan tentang: 1) apa yang dimaksud dengan SADARI?, 2) kapan perempuan sebaiknya melakukan SADARI usia?, 3) apa definisi kanker payudara dan stadium kanker payudara?, 4) pada saat melakukan SADARI dengan posisi berbaring, sewaktu memeriksa payudara sebelah kanan, meletakkan bantal di bawah bahu kanan dan lengan kanan diposisikan di atas kepala, gerakan ini bertujuan untuk?, 5) pada saat melakukan SADARI dilakukan perabaan terhadap payudara dengan menekan secara mantap namun lembut dengan jari yang merapat dan gerakan dari atas ke bawah, sisi ke sisi (seperti mengepel lantai) dan melingkar seperti lingkaran obat nyamuk pada setiap gerakan, pastikan seluruh bagian payudara teraba seluruhnya, gerakan ini bertujuan untuk?, 5) bagaimana teknis pelaksanaan SADARI?, 6) mengapa SADARI setiap bulan sangat penting dilakukan secara teratur?.

Sedangkan pertanyaan yang paling banyak dijawab salah adalah tentang: 1) kapan sebaiknya waktu yang tepat melakukan SADARI secara teratur setiap bulan?, 2) pada saat melakukan SADARI kita masih di depan cermin, lalu menekan atau memencet puting susu dengan menggunakan ibu jari dan jari telunjuk?, 3) pelaksanaan SADARI dilakukan dengan urutan posisi pemeriksaan sebagai berikut!, 4) bagian tangan yang digunakan untuk meraba payudara karena bagian ini memiliki sensitifitas yang tinggi adalah bagian?, 5) kapan seorang wanita penting melakukan sadari?.

Setelah diberikan penyuluhan diketahui bahwa peningkatan pengetahuan di setiap item pertanyaan sebesar 30-60\% mengalami perubahan yang signifikan adalah pertanyaan tentang: kapan sebaiknya waktu yang tepat melakukan SADARI secara teratur setiap bulan, dimana sebelum sebelum penyuluhan yang menjawab dengan tepat adalah 36 orang $(39,6 \%)$ dan setelah penyuluhan yang menjawab dengan tepat sebanyak 81 orang $(89,0 \%)$, sedangkan pertanyaan yang mengalami perubahan yang tidak signifikan adalah pertanyaan tentang: kapankah seorang wanita penting melakukan SADARI, dimana sebelum penyuluhan yang menjawab dengan tepat sebanyak 36 orang $(39,6 \%)$ dan setelah penyuluhan yang menjawab dengan tepat sebanyak 40 orang $(44,0 \%)$. Sebelum penyuluhan, diketahui bahwa sebagian besar responden berpengetahuan kurang dengan jumlah sebanyak 8 orang $(8,8 \%)$ dan setelah diberikan penyuluhan diketahui bahwa terjadi perubahan pengetahuan dimana sebagian besar responden berpengetahuan baik dengan jumlah 68 orang $(74,7 \%)$.

Hal ini berarti bahwa telah terjadi peningkatan pengetahuan siswi setelah diberikan pendidikan kesehatan, terlihat bahwa sebelum diberikan promosi kesehatan tentang SADARI, pengetahuan siswa kurang baik. Namun setelah diberikan pendidikan kesehatan, siswi mendapatkan informasi tentang SADARI dan memiliki pengetahuan yang baik. SADARI memang perlu dan harus dilakukan setiap perempuan yang telah mengalami haid untuk mendeteksi secara dini kanker payudara.

Hasil penelitian berdasarkan tingkat pengetahuan siswi tentang pemeriksaan SADARI didukung oleh hasil penelitian Suastina, Ticoalu dan Onibala (2013), yang menyatakan bahwa pengetahuan sebelum diberikan pendidikan kesehatan tentang 
SADARI sebagai deteksi dini kanker payudara menunjukkan bahwa sebagian besar siswi dikategorikan kurang sebanyak $62 \%$ dan setelah diberikan pendidikan kesehatan tentang SADARI $81.4 \%$ siswi pengetahuannya dikategorikan baik.

Hasil penelitian tentang pengaruh pendidikan tentang SADARI diketahui bahwa semua pernyataan sikap mengalami peningkatan. Sebelum penyuluhan sebagian besar responden menjawab tidak setuju pada pernyataan. Mengetahui lebih dini adanya benjolan pada payudara dan ternyata adalah kanker maka harapan untuk sembuh akan lebih besar dan sebaiknya melakukan SADARI secara teratur sebanyak 1 orang $(1,1 \%)$, Jika ditemukan benjolan di payudara saat melakukan SADARI sebanyak 1 orang $(1,1 \%)$, jangan menunda untuk melakukan pemeriksaan ke dokter untuk penanganan selanjutnya sebanyak $1 \quad(1,1 \%)$, Sadari sebaiknya dilakukan setiap bulan yaitu 1 minggu setelah haid terakhir sebanyak 1 $(1,1 \%)$.

Pada saat mendapatkan informasi tentang sadari untuk pemeriksaan dini kanker payudara sebaiknya dilakukan sebanyak 4 orang $(4,4 \%)$. Jika keluarga melarang untuk melakukan sadari sebanyak 3 orang (3,3\%), maka akan tetap melakukannya sebanyak 1 orang $(1,1 \%)$. Semakin dini ditemukan kanker payudara semakin mudah untuk disembuhkan. Diri sendiri yang paling tahu dan merasakan perubahan yang terjadi pada payudara sebanyak 8 orang $(8,8 \%)$. Sebaiknya informasi mengenai SADARI diperoleh langsung dari petugas kesehatan, dan dukungan teman sebaya sangat penting dalam pelaksanaan SADARI sebanyak 3 orang $(3,3 \%)$.

Pendidikan kesehatan tentang pemeriksaan SADARI sangat mem pengaruhi sikap, yaitu kegiatan yang dapat meningkatkan kesehatan diri sendiri. Pengetahuan akan berpengaruh terhadap sikap seseorang karena pengetahuan terus bertambah sesuai dengan proses pengalaman yang dialami. Proses kognitif dapat terjadi pada saat individu memperoleh informasi mengenai objek sikap melalui pengalaman langsung, media massa, pengaruh orang lain yang dianggap penting, keluarga, pendidikan. Setiap yang didasari oleh pengetahuan akan lebih langgeng daripada sikap tanpa didasari pengetahuan.

\section{KESIMPULAN}

Berdasarkan hasil dan pembahasan penelitian, disimpulkan bahwa: 1) ada pengaruh pendidikan kesehatan tentang pemeriksaan SADARI terhadap pengetahuan siswi di SMK Swasta Yapim Balige; dan 2) ada pengaruh pendidikan kesehatan tentang pemeriksaan SADARI terhadap sikap siswi di SMK Swasta Yapim Balige

\section{SARAN}

Diharapkan kepada petugas kesehatan untuk selalu memberikan edukasi tentang pentingnya SADARI sebagai deteksi dini kanker payudara

\section{REFERENSI}

Bustan, M. (2007). Epidemiologi Penyakit Tidak Menular. Jakarta: Rineka Cipta.

Depkes RI. (2009). Buku Saku Pencegahan Kanker Leher Rahim dan Payudara. Depkes RI.

Dalimartha, S. (2004). Deteksi Dini Kanker dan Simplisia Antikanker. Jakarta: Penebar Swadaya.

Dianawati, A. (2003). Pendidikan dan Seks untuk Remaja. Jakarta: Kawan Pustaka.

Kemkes RI. (2017). Situasi Penyakit Kanker Data dan Informasi profil Kesehatan Indonesia. [internet]. 2017. Tersedia pada: http://www.depkes.go.id/ resources/download/pustadin/lainlain/Data dan Informasi Kesehatan Profil Kesehatan Indonesia 2016smller size - web.pdf

Kemkes RI. (2015). Buletin Kanker. Pusat Data dan Informasi Kementrian Kesehatan RI 2015. Jakarta: Kemenkes RI

Kemkes RI. (2009). Pengahan Kanker Leher Rahim dan Kanker Payudara. 
Jakarta: Kemkes RI. Mardiana. 2007. Kanker Pada Wanita. Jakarta:

Swadaya.

Rama, D. (2009). Panduan Lengkap Mengenai Kanker. Yogyakarta: Media Pustaka.

Saryono, RP. (2009). Perawatan Payudara. Yogyakarta: Nuha Medika.

Setiawan, D. (2014). Deteksi Dini Kanker dan Simplisia Anti Kanker. Jakarta: Penebar Swadaya.

Sudoyo, AW. (2007). Melantun Kebersamaan Berantas Yayasan Kanker Indonesia. Jakarta: Harapan Terpadu [internet]. Tersedia pada: yayasan kanker indonesia.org

Suryaningsih, S. (2009). Kupas Tuntas Kanker Payudara. Yogyakarta: Paradigma Indonesia.

Widyastuti, Y. (2009). Kesehatan Reproduksi (Ilmu Kesehatan). Yogyakarta: Fitramaya. 